Águas Subterrâneas (2012) 26(1): 1-17.

\title{
NEOTECTÔNICA E ESTRUTURAÇ̃̃O DOS SISTEMAS HIDROGEOLÓGICOS DA REGIÃO DE CASTANHAL / PA
}

\author{
NEOTECTONIC AND STRUCTURE OF HYDROGEOLOGICAL \\ SYSTEMS OF CASTANHAL/PA REGION
}

Iris Celeste Nascimento Bandeira ${ }^{1}$, Francisco Assis Matos de Abreu $^{2}$

Artigo recebido em: 11/11/2010 e aceito para publicação em: 16/11/2011

\begin{abstract}
The morphostructural and hydrogeological study conducted at Castanhal - PA in two different scales, $1: 100,000$ and 1:25,000, allowed the understanding of relationships between hydrogeological systems' geometrical elements and structural elements related to neotectonic events as a basis to determine, among other aspects, potential recharge areas of these systems. The morphostructural study, aided by geophysical data collected, showed that the area has a structural control related to a neotectonic pulse that triggered the reactivation of faults with NW-SE, NESW, EW and NS directions. This lead to anomalies and changes in drainage patterns and conditioned the establishment of units where flat-topped hills, pediplanized hills, and major river plains were produced. These faults may be compatible with a stress field that generated a geometric arrangement characterized by tectonic blocks and a destral kinematic configuration, where tensile fault were formed in NW-SE direction, setting up important conduits for the recharge of hydrogeological systems. The area studied is composed by three hydrological systems: Superior, Barreiras, and Pirabas, which present variable depth related to the vertical rupture of rock layers, promoted by neotectonic faults. These hydrological systems, considered confined (Pirabas) to semi-confined (Barreiras), have a recharge component from fault zones and fault trace of NW-SE direction. The recharge of free aquifers occurs through direct precipitation, from rain water at the Midwest and northeast of the studied area.
\end{abstract}

Keywords: Hydrogeology. Neotectonics. Recharge. Catanhal-PA, Brazil.

Resumo: O estudo morfoestrutural e hidrogeológico realizado no município de Castanhal - PA em duas escalas distintas, 1:100.000 e 1:25.000, permitiu avançar no entendimento das relações entre elementos geométricos dos sistemas hidrogeológicos e elementos estruturais relacionados aos eventos neotectônicos como base para determinar, entre outros aspectos, áreas potenciais de recarga destes sistemas. O estudo morfoestrutural auxiliado pelos dados geofísicos levantados mostrou que a área tem um controle estrutural relacionado a um pulso neotectônico, responsável pela reativação de falhas de direção NW-SE, NE-SW, E-W e N-S, as quais provocaram anomalias e mudanças nos padrões de drenagem, assim como condicionaram o estabelecimento de unidades de relevo onde se destacam planícies fluviais, colinas pediplanizadas e colinas de topo aplainado. Essas falhas podem ser compatibilizadas em um regime de esforço que gerou um arranjo geométrico caracterizado por blocos tectônicos, bem como um quadro cinemático destral, onde se formaram falhas trativas na direção NW-SE, configurando importantes condutos para a recarga dos sistemas hidrogeológicos. Na área em consideração foram reconhecidos três sistemas hidrogeológicos: Superior, Barreiras e Pirabas que apresentam profundidades variáveis, relacionadas aos deslocamentos verticais, provocados por falhas neotectônicas. Os sistemas hidrogeológicos considerados como confinados (Pirabas) a semiconfinados (Barreiras) têm uma componente de recarga a partir de zonas de falhas e fraturas trativas de direção NW - SE. Já a recarga dos sistemas hidrogeológicos livres se dá pela precipitação direta, a partir da água da chuva na porção centro-oeste e nordeste da área de estudo.

Palavras Chaves: Hidrogeologia. Neotectônica. Recarga. Castanhal-PA.

\section{INTRODUÇÃO}

A água é um dos recursos naturais mais consumidos pela sociedade moderna. Atualmente muito se fala em racionalização de sua utilização, pois acredita-se que, apesar da abundância deste recurso em regiões como a Amazônia, havendo desperdício e um mau gerenciamento o recurso pode sofrer um déficit em termos de quantidade e qualidade.

Para que tal cenário não venha a acontecer é necessário um gerenciamento adequado, sustentado por conhecimentos científicos que priorizem a compreensão do comportamento e da interrelação que existe entre águas superficiais e subterrâneas. Com base em estudos dessa natureza se poderá

\footnotetext{
${ }^{1}$ CPRM. (bandeira4@yahoo.com.br)

${ }^{2}$ Universidade Federal do Pará/UFPA. (famatos@ufpa.br)
} 
avaliar mais rapidamente, por exemplo, impactos ambientais sobre as águas de uma determinada região. O nordeste do Pará, inserido no contexto amazônico, onde ocorrem de forma principal os sistemas hidrogeológicos Barreiras e Pirabas, considerados grandes reservatórios de água subterrânea do Brasil (OLIVEIRA, 2003), é ainda pouco conhecido em termos de parâmetros hidrogeológicos.

Desta forma, este trabalho tem como objetivo o entendimento da relação entre elementos geométricos dos sistemas hidrogeológicos existentes ao norte da cidade de Castanhal-PA, e os aspectos estruturais, principalmente aqueles relacionados aos eventos neotectônicos, como base para determinar áreas potenciais de recarga destes sistemas.

Para atingir este objetivo, o trabalho integrou dois tipos de estudo: morfoestrutural e hidrogeológico. Para esta integração seguiu-se a seguinte metodologia: pesquisa bibliográfica e coleta de informações técnicas; geração de um sistema de informações geográficas - SIG, para auxiliar na elaboração dos mapas constantes neste trabalho; análise da drenagem e do relevo em escala regional e de semidetalhe, conforme metodologia de Stewart e Hancock (1994), Soares e Fiori (1976), Howard (1967) e Costa (2004); campanhas de campo (abril, setembro e novembro de 2007), para coleta de dados hidrogeológicos e geofísicos; elaboração de seções e perfis geofísicos (sondagem elétrica vertical) e caracterização hidrogeológica (geometria dos sistemas hidrogeológicos, mapeamento de fluxo e determinação das áreas de recarga).

\section{A ÁREA EM CONSIDERAÇÃO}

A área estudada compreende dois recortes diferentes. No primeiro, de cunho regional, foram realizados estudos morfoestruturais em escala 1:100.000 na porção nordeste do Estado do Pará, mais especificamente na porção oeste da folha SA23 - V - C - I (Figura 1). Está área engloba a maior parte do município de Castanhal-PA, a porção oeste de São Francisco do Pará, norte de Inhangapi e São Miguel do Guamá, leste de Santa Izabel do Pará, leste de Santo Antônio do Tauá e Vigia, sul de Terra Alta, São Caetano de Odivelas e de Marapanim.
No segundo recorte foi feito um estudo morfoestrutural e hidrogeológico na escala 1:25.000, cuja a área investigada corresponde a Folha SA-23 - V C - I -1-SO, ou seja, recobre o centro oeste do município de Castanhal e sul do município de Santo Antônio do Tauá (Figura 1). Além destes estudos, foi feita uma revisão bibliográfica sobre os aspectos geológicos e climáticos, na área do segundo recorte, com o objetivo de embasar a análise hidrogeológica.

\section{CLIMA}

A recarga dos aquíferos superficiais está intimamente ligada à retenção hídrica e tem relação direta com a incidência das chuvas. Portanto, é de extrema importância entender o comportamento dos aspectos climáticos de uma dada região para conhecer a sua potencialidade hídrica.

De acordo com os dados de 2003 a 2007, fornecidos pelo Instituto Nacional de Meteorologia - INMET/ $2^{\circ}$ Distrito de Meteorologia/PA, o clima da região de Castanhal corresponde ao tipo "Af", da classificação de Köppen, pois é caracterizado pela ocorrência de precipitação em todos os meses do ano, com média anual entre os anos 2003 a 2007 de $2103 \mathrm{~mm} / \mathrm{ano}$, ocasionando uma temperatura elevada com média de $26^{\circ} \mathrm{C}$ e máxima de $32^{\circ} \mathrm{C}$. Possui pequena amplitude térmica e umidade relativa do ar em torno de $82 \%$. A estação chuvosa ocorre no período de janeiro a maio e a menos chuvosa de junho a dezembro, sendo os meses de setembro e novembro os menos chuvosos.

Lima et al. (1994), elaboraram um balanço hídrico para a região de Castanhal/PA, baseado em dados do ano de 1975 a 1987 e fundamentado na aplicação do princípio de conservação da massa de água, proposto por Thornthwaite e Mather (1955) que além da obtenção da classificação climática, também indica o comportamento da entrada e saída da água no solo. Baseado nesse tipo de dado obteve-se a figura 2 , que apresenta o comportamento das linhas de P, DEF e EXC, onde se verifica que durante o período de janeiro a agosto, o comportamento da linha de excedência é semelhante ao da precipitação. Tal comportamento é explicado pelo grande volume de água disponível durante esse período. A deficiência, por sua vez, permanece zero até agosto. A partir de setembro passa a haver um déficit. 

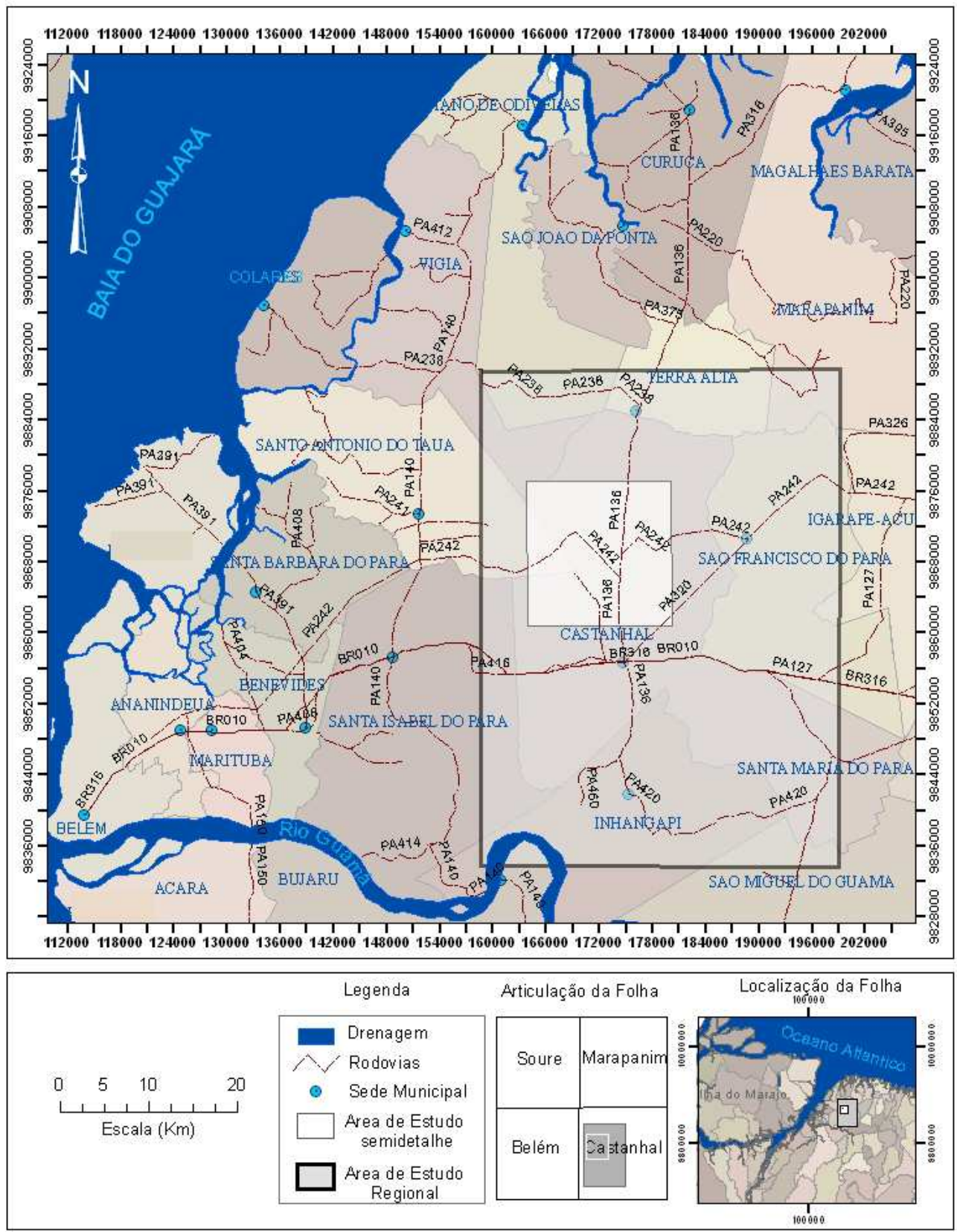

Figura 1 - Mapa de localização da área de estudo

Figure 1 - Location map of the area studied

Fonte: SETRANS (2000)

Source: SETRANS (2000) 


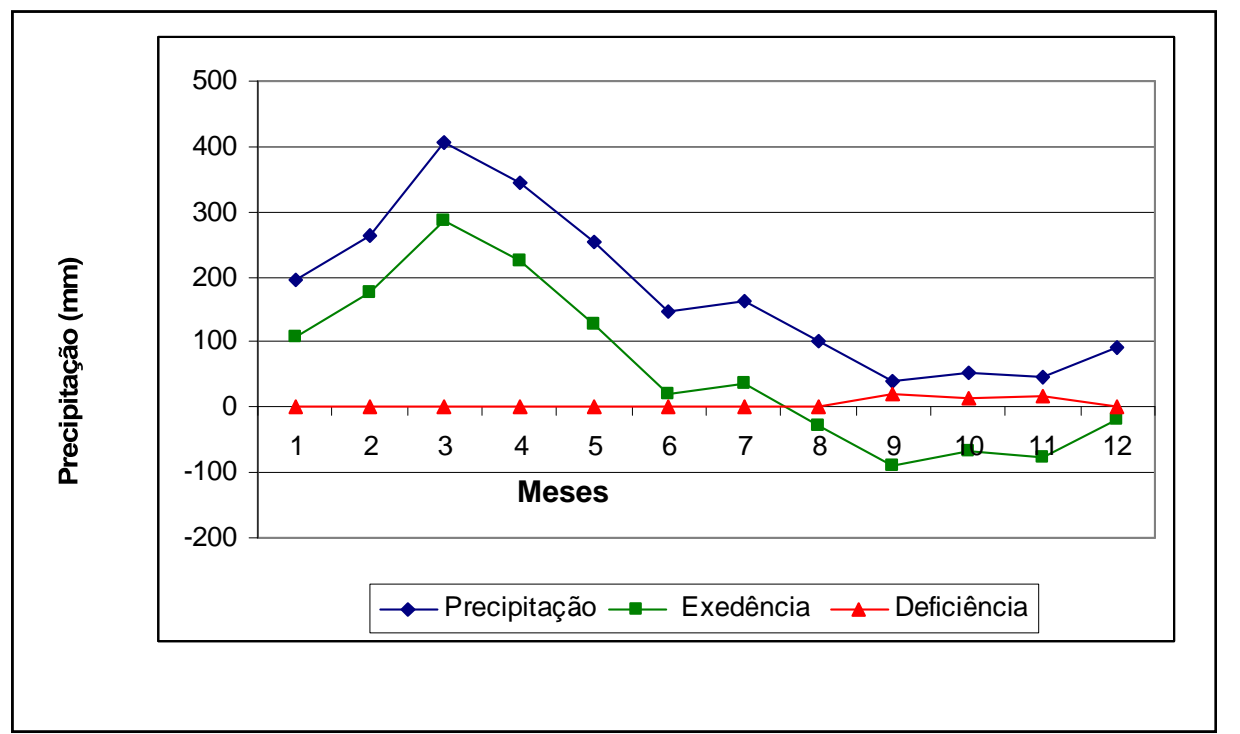

Figura 2 - Representação gráfica das linhas P, DEF e EXC hidrica para a região de Castanhal/PA (Período de 1975 a 1987)

Figure 2 - Graphical representation of P, DEF and EXC lines, hidric to Castanhal / PA region (Period 19751987)

\section{GEOLOGIA}

As rochas que afloram no município de

Dados de poços profundos (OLIVEIRA, 2003) Castanhal são caracterizadas como sedimentares, onde se destacam: o Grupo Barreiras, Sedimentos Pós-Barreiras e Sedimentos Recentes (SOUZA JUNIOR; QUADROS; BEZERRA, 1992 apud BANDEIRA; ABREU, 2009), conforme figura $3 \mathrm{e}$ mostram que este pacote sedimentar prolonga-se em subsuperfície, englobando rochas do Grupo Barreiras e Pirabas, cuja espessura total do pacote sedimentar é ainda desconhecida. 4.

\begin{tabular}{|c|c|c|c|c|}
\hline Era & Período & Época & Unidades & Descrição \\
\hline \multirow{4}{*}{ 苞 } & \multirow{3}{*}{ 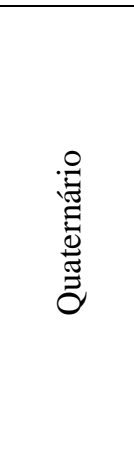 } & \multirow{2}{*}{$\begin{array}{l}\stackrel{0}{0} \\
\stackrel{0}{0} \\
\frac{0}{0} \\
\frac{1}{1}\end{array}$} & $\begin{array}{l}\text { Sedimentos Re- } \\
\text { centes }\end{array}$ & $\begin{array}{l}\text { Argilas de coloração branca acinzentada, com manchas } \\
\text { vermelhas a amareladas devido a oxidação do ferro. }\end{array}$ \\
\hline & & & Pós-Barreiras & $\begin{array}{l}\text { Sedimentos areno-argilosos, maciços, coloração amarela, } \\
\text { apresentando grânulos de quartzo e concreções ferruginosas } \\
\text { dispersas aleatoriamente. }\end{array}$ \\
\hline & & $\begin{array}{l}0 \\
\stackrel{0}{0} \\
\frac{0}{0} \\
\frac{0}{2} \\
\frac{0}{2}\end{array}$ & \multirow{2}{*}{ Grupo Barreiras } & \multirow{2}{*}{$\begin{array}{l}\text { Sedimentos argilosos com laminação plano paralela, colora- } \\
\text { ção vermelha amarelada com tons esbranquiçados, biotur- } \\
\text { bados, localmente gretas de contração; sedimentos arenosos } \\
\text { de granulação fina a média, estratificações cruzadas do tipo } \\
\text { acanalada (Tangencial), sigmoidal e estratificações de maré; } \\
\text { sedimentos areno-argilosos maciços ou com estratificações } \\
\text { incipientes; } \\
\text { conglomerados com seixos de quartzo e quartzito. }\end{array}$} \\
\hline & 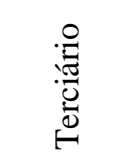 & 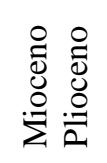 & & \\
\hline
\end{tabular}

Figura 3 - Coluna Estratigráfica da Região de Castanhal

Figure 3 - Stratigraphic Column of Castanhal Region

Fonte: Souza Junior, Quadros e Bezerra, 1992 apud Bandeira e Abreu (2009)

Source: Souza Junior, Quadros e Bezerra, 1992 apud Bandeira e Abreu (2009) 


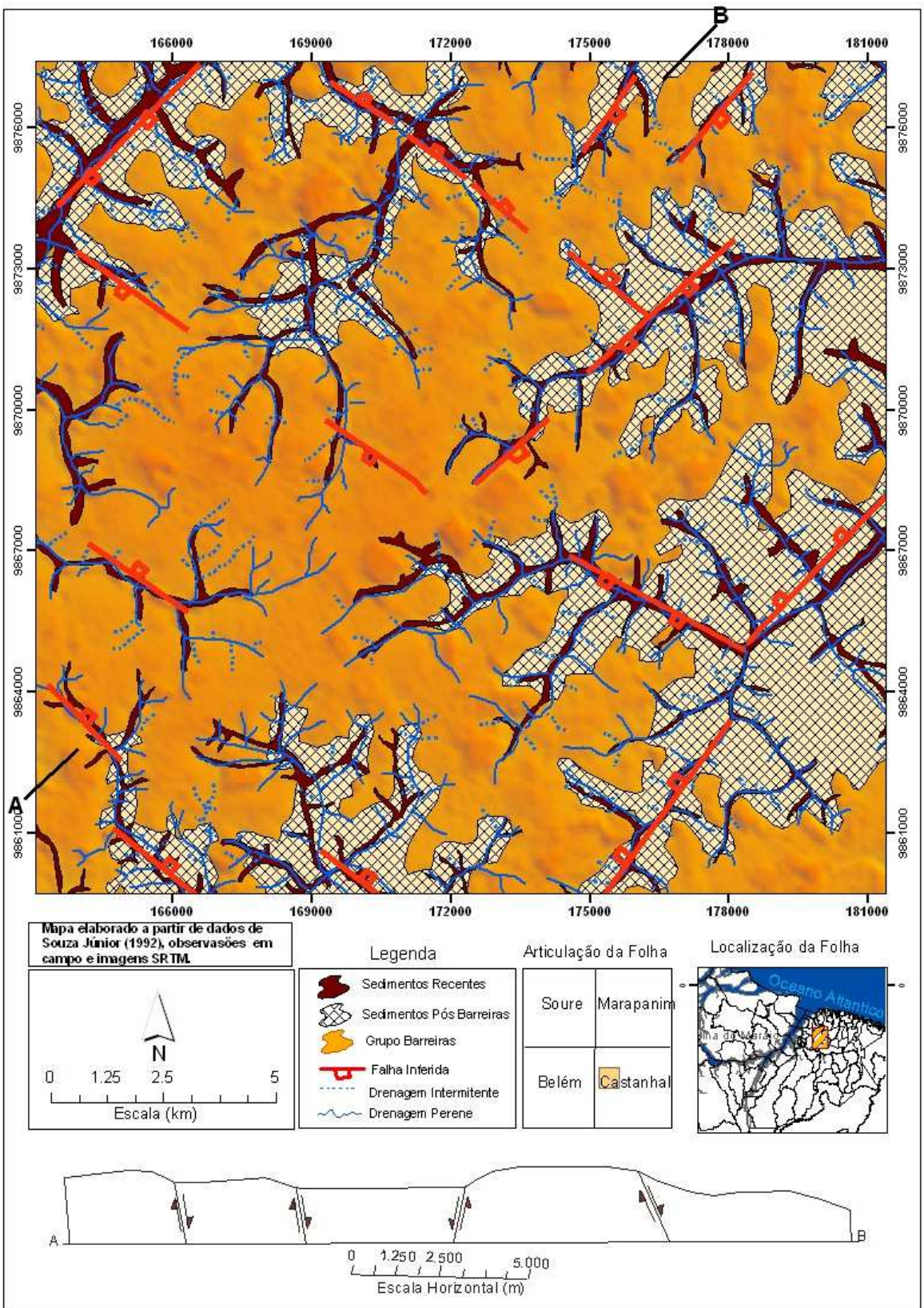

Figura 4 - Mapa Geológico da Folha SA-23 - V - C - I -1-SO

Figure 4 - Sheet SA-23 - V - C - I -1-SO geological Map

Fonte: Bandeira e Abreu (2009)

Source: Bandeira e Abreu (2009)

\section{ANÁLISE MORFOESTRUTURAL}

Segundo Argento (2001), a análise morfoestrutural é uma ferramenta fundamental para delinear a causa dos fatos geomorfológicos derivados dos grandes aspectos geotectônicos, dos grandes arranjos estruturais e, eventualmente, da predominância de uma litologia definida.

\section{Análise Morfoestrutural Regional}

Com base na analise do relevo e da drenagem da porção oeste da folha SA-23 -V - C -I observou-se que a área de estudo está dentro de um quadro tectônico regional, onde os sismos não são tão freqüientes e nem tão intensos como em regiões de bordas de placas litosféricas, mas são representantes da atual dinâmica intraplaca e essenciais para estudos de neotectônica.

Berrocal et al. (1984) fizeram um inventário dos sismos ocorridos até 1981, no qual estão registrados os sismos ocorridos no nordeste do estado Pará (Tabela 1): 
Baseado nos dados históricos dos sismos ocorridos, pode se dizer que na área o quadro morfoestrutural é considerado morfotectônico, com alguns dados geométricos e cinemáticos observados e descritos a seguir.

Tabela 1 - Dados de sismos sentidos no nordeste do estado do Pará

Table 1 - Data of seismic events at the northeastern of Para state

\begin{tabular}{|c|c|c|c|}
\hline Registro & Local do tremor & Período & $\begin{array}{c}\text { Magnitude } \\
\text { na escala } \\
\text { Richter }\end{array}$ \\
\hline $1^{0}$ & Vigia & 12 de julho de 1860 & \\
\hline $2^{\circ}$ & Belém & 07 de outubro de 1946 & \\
\hline $3^{\circ}$ & $\begin{array}{l}\text { Belém, Ananindeua, Mosqueiro, } \\
\text { Abaetetuba, Castanhal e Vigia }\end{array}$ & 12 de janeiro de 1970 & 4,5 \\
\hline $4^{\circ}$ & Nordeste da ilha do Marajó & 02 de agosto de 1977 & \\
\hline $5^{\circ}$ & llha do Marajó & 18 de outubro de 1980 & 3,1 \\
\hline $6^{\circ}$ & $\begin{array}{c}\text { Lat } 02,83^{\circ} \mathrm{S} / \text { Long } 49,13^{\circ} \mathrm{W} \text {, nor- } \\
\text { deste do Pará }\end{array}$ & 14 de novembro de 1980 & 2,8 \\
\hline $7^{0}$ & $\begin{array}{c}\text { Lat } 02,85^{\circ} \mathrm{S} / \text { Long } 50,60^{\circ} \mathrm{W} \text {, } \\
\text { nordeste do Pará }\end{array}$ & 09 de fevereiro de 1981 & 2,7 \\
\hline
\end{tabular}

Fonte: Berrocal et al. (1984)

\section{Aspectos geométricos}

A integração dos dados de relevo e de drenagem associados à geologia da área permitiu gerar um mapa morfoestrutural (Figura 5) que mostra:

$\checkmark \quad$ Três unidades morfológicas onde se observam alinhamentos de direção: $\mathrm{N}^{\circ}-10^{\circ} \mathrm{W}, \mathrm{N} 20^{\circ}$ $30^{\circ} \mathrm{W}, \mathrm{N} 40^{\circ}-50^{\circ} \mathrm{W}, \mathrm{N} 60^{\circ}-70^{\circ} \mathrm{W}, \mathrm{E}-\mathrm{W}, \mathrm{N} 30^{\circ}-40^{\circ} \mathrm{E}$, $\mathrm{N} 40^{\circ}-50^{\circ} \mathrm{E}$ e $\mathrm{N} 60^{\circ}-70^{\circ} \mathrm{E}$;

$\checkmark \quad$ Padrões retilíneos e assimetrias de drenagens, evidenciando um controle estrutural caracterizado por falhas normais, responsáveis por deslocamentos verticais de blocos. Estas falhas possuem duas direções preferências NE-SW e NW-SE.

$\mathrm{Na}$ porção noroeste da área (Figura 5) observam-se falhas de direção NE-SW, com mergulhos no sentido SE, indicando um abatimento de blocos nesse mesmo sentido. Na porção centro oeste observam-se falhas de direção NW-SE formando um graben. A sudeste as falhas de direção NE-SW possuem mergulhos no sentido SE.

\section{Aspectos Cinemáticos}

$\mathrm{Na}$ área foram observados indicadores de movimentação tectônica, tais como: assimetria da drenagem (indicativos de movimentação vertical) e mudanças no padrão de drenagem; trechos retilíneos que se tornam sinuosos com brusca mudança de orientação, o que pode significar uma falha ou um bloco abatido; anomalias em $\mathrm{Z}$ e S, controladas por deslocamentos de superfícies estruturais, que podem indicar movimentação de blocos.

A integração das informações dos aspectos geométricos e cinemáticos do relevo e da drenagem pode associar esses elementos a um controle tectônico, que geralmente está relacionado a modelos de deformação.

Nesse caso, o modelo utilizado para compatibilizar e explicar esses elementos estruturais geométricos foi o de Riedel que trata da deformação rúptil não coaxial.

Verificou-se que a área tem suas estruturas compatibilizadas ao funcionamento de um binário destral E-W, gerando dois planos principais de direção $\mathrm{N} 60^{\circ}-70^{\circ} \mathrm{W}$, com possível deslocamento destral (não observado) e outro lineamento N10 $20^{\circ} \mathrm{W}$ com indicação de movimento sinistral, comprovado pelas formas em " $\mathrm{S}$ " nas drenagens. Além destes planos, existem fraturas sintéticas secundárias na direção $\mathrm{N} 60^{\circ}-70^{\circ} \mathrm{E}$ com indicação de deslocamento destral, verificado pelas formas em " $Z$ " nas drenagens nestas direções.

Os alinhamentos de direção $\mathrm{N} 20^{\circ}-40^{\circ} \mathrm{W}$, correspondentes aos Igarapés Pau Amarelo e Rodrigues, Maracanã, estariam encaixadas, segundo o modelo proposto, nos planos distensivos. Estes segmentos são áreas de prováveis deslocamentos verticais e apresentam maior favorabilidade à penetração vertical da água, podendo ser considerado 
como zonas de recarga dos aquíferos rasos e profundos.

Esses dados do meio físico estão condizentes com o padrão regional apresentado por Costa et al. (1996), no qual mostram que a neotectônica do nordeste do Pará, onde está inserida a área de estudo, é caracterizada por falhas normais com direção NW-SE, correspondente à transtensão vinculada à atuação de sistemas transcorrentes destrais.

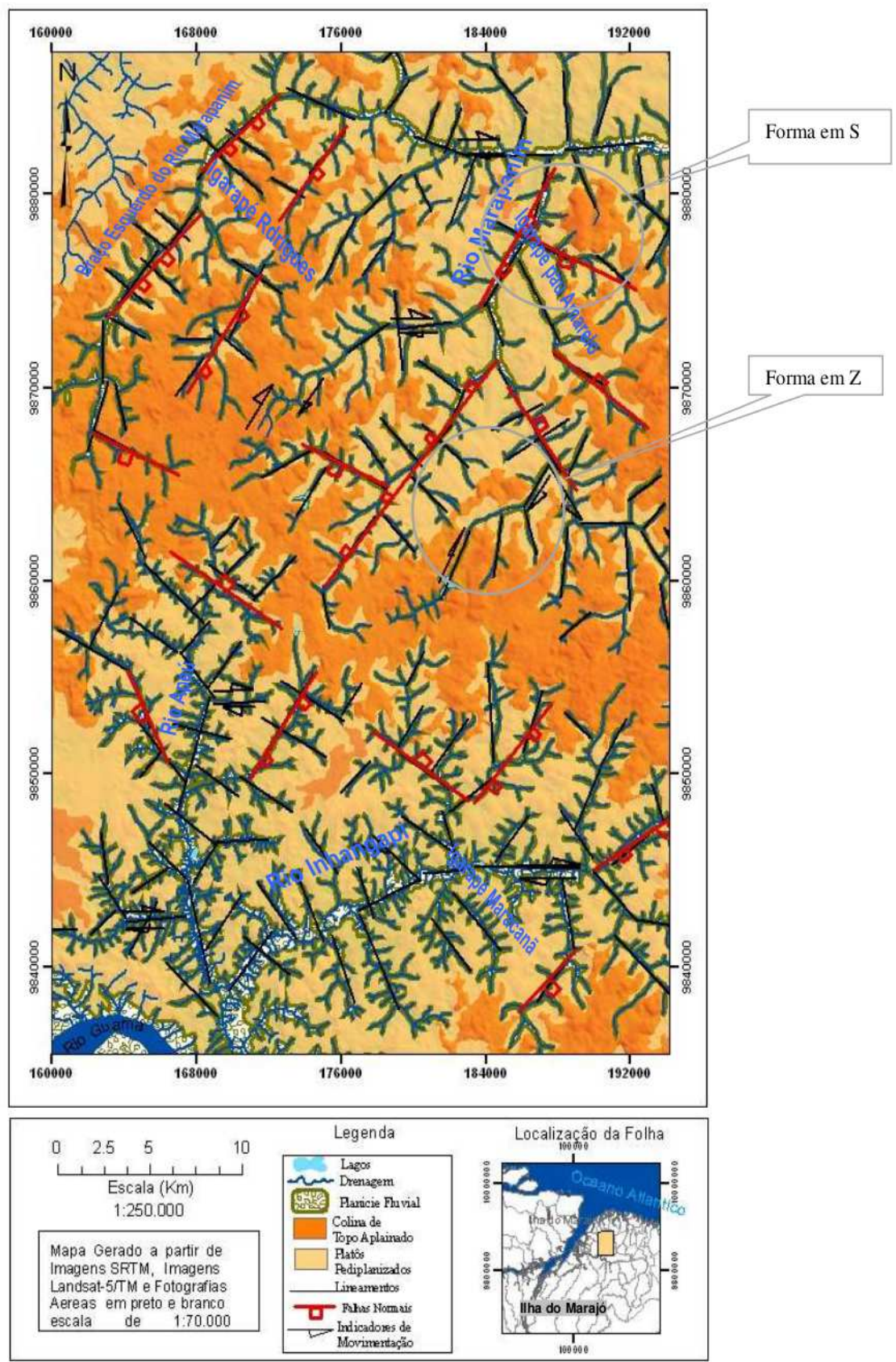

Figura 5 -Mapa Morfoestrutural Regional mostrando as principais Unidades de re levo condicionadas a um arranjo geométrico estruturado

Figure 5 - Morphostructural map showing the main terrain units conditioned by a geometric structure arrangement 
Tabela 2 - Descrição dos blocos estruturais do mapa morfoestrutural da Folha SA-23 - V - C - I -1- SO Table 2 - Building blocks' description of Sheet SA-23 - V - C - I - 1--SO morphostructural map

\begin{tabular}{|c|c|c|c|c|}
\hline Bloco & Localização & Dimensões das arestas & $\begin{array}{c}\text { Direção } \\
\text { principal }\end{array}$ & Abatimento \\
\hline 2 & Noroeste & $\begin{array}{l}\text { Aresta maior em torno de } 7 \mathrm{~km} \mathrm{e} \\
\text { a menor em torno de } 6 \mathrm{~km}\end{array}$ & NE-SW & $\begin{array}{l}\text { Abatimento em relação ao blo- } \\
\text { co } 1 \text { no sentido SE }\end{array}$ \\
\hline 4 & Nordeste & $\begin{array}{l}\text { Aresta maior com valor de } 7,5 \\
\mathrm{~km} \text { e a menor em torno de } 5 \mathrm{~km}\end{array}$ & NW-SE & $\begin{array}{l}\text { Abatimento em relação ao blo- } \\
\text { co } 7 \text { no sentido NE }\end{array}$ \\
\hline 7 & Central & $\begin{array}{l}\text { Aresta maior próximo de } 7 \mathrm{~km} \mathrm{e} \\
\text { a menor em torno de } 5,5 \mathrm{~km}\end{array}$ & NE-SW & $\begin{array}{c}\text { É caracterizado como um horst, } \\
\text { por ser um bloco alto, limitado } \\
\text { por falhas normais. }\end{array}$ \\
\hline 8 & Leste & $\begin{array}{l}\text { Aresta maior em torno de } 8 \mathrm{~km} \mathrm{e} \\
\text { a menor em torno de } 6,5 \mathrm{Km}\end{array}$ & NE-SW. & $\begin{array}{l}\text { Abatido no sentido SE em rela- } \\
\text { ção ao bloco } 7 \text { e no sentido NW } \\
\text { em relação ao bloco } 12 \text {, caracte- } \\
\text { rizando um graben. }\end{array}$ \\
\hline 10 & Centro-oeste & $\begin{array}{c}\text { Aresta maior em torno de } 8 \mathrm{~km} \mathrm{e} \\
\text { a menor de } 6,2 \mathrm{~km}\end{array}$ & $\mathrm{NW}-\mathrm{SE}$ & Abatimento no sentido SW. \\
\hline 11 & Sudeste & $\begin{array}{c}\text { Aresta maior em torno de } 7,5 \mathrm{~km} \\
\text { e a menor em torno de } 5,3 \mathrm{~km}\end{array}$ & $\mathrm{NW}-\mathrm{SE}$ & Abatimento no sentido SW. \\
\hline
\end{tabular}

\section{Análise Morfoestrutural em Escala de Semide- talhe}

$\mathrm{O}$ estudo morfoestrutural em semidetalhe do relevo e da drenagem da Folha SA-23 - V - C I -1-SO, mostrou que a drenagem apresenta padrões como treliça, retangular e paralelo, anomalias como retilinearidade, aparecimento abrupto e localizado de meandros, assimetrias distintas relacionadas ao comprimento dos seus afluentes, que comprovam o abatimento de blocos, estreitamento anômalo de vales ou canais, curvas anômalas e um relevo alinhado segundo duas direções principais: $\mathrm{N} 50^{\circ}-60^{\circ} \mathrm{W}$ e $\mathrm{N} 40^{\circ}-50^{\circ} \mathrm{E}$.

Estas evidências reforçam a ideia de que a área em questão reflete um controle estrutural, no qual foi possível adotar a metodologia proposta por Costa (2004), que se baseia nos padrões da drenagem e do relevo para esboçar um arranjo geométrico bidimensional da área. Com base na análise morfoestrutural foi gerado um mapa morfoestrutural onde se destacam três unidades morfológicas, seccionadas por alinhamentos de drenagens e de relevo com direções NW- SE, NE-SW, N-S, E-W, que formam polígonos, na sua grande maioria retangulares (Figura 6).

Os alinhamentos maiores, de direção NE$\mathrm{SW}$, seccionados por alinhamentos menores de direção NW-SE, definiram 16 blocos com arestas maiores variando entre 5 e $8 \mathrm{Km}$ e as menores variam entre 3 e $7 \mathrm{~km}$. Estes blocos foram abatidos em quatro sentidos principais NE, SW, NW, SE, descritos na tabela 2:

A análise integrada da drenagem e do relevo, relacionadas às informações geológicas do terreno e dos perfis geofísicos, mostrou que a área de estudo em escala de semi-detalhe 1:25.000, assim como a de estudo regional 1:100.000 enquadram-se no contexto regional descrito por Costa et al. (1996), ou seja, estão inseridas num contexto estrutural neotectônico, onde as direções NW-SE seriam as mais distensivas. 


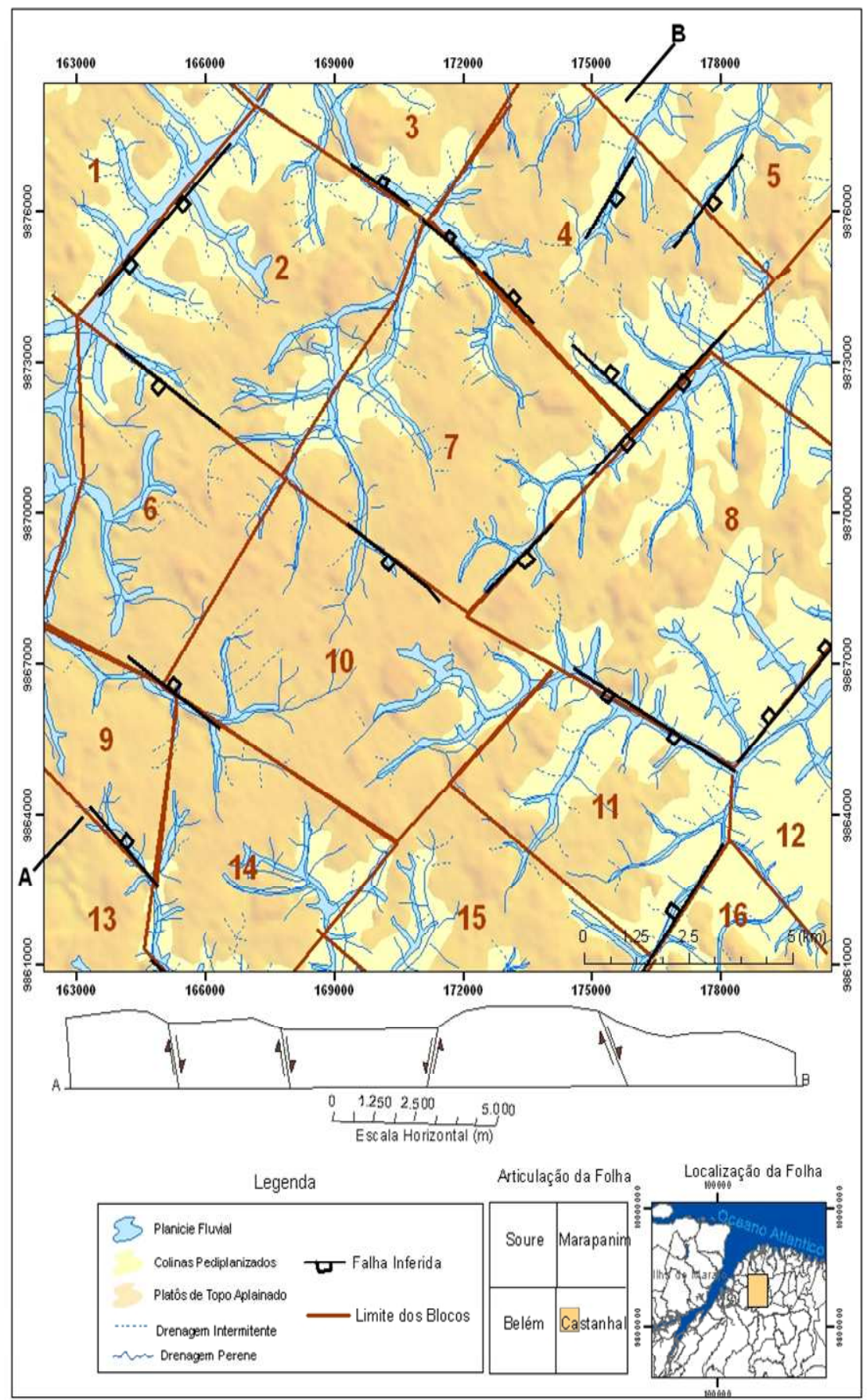

Figura 6 - Mapa morfoestrutural da Folha SA-23 - V - C - I -1-SO, Mostrando a relação entre morfologia e os 16 blocos estruturais

Figure 6 -Sheet SA - $23-$ V - C - I - 1-SO morphostructural map, showing the relationship between morphology and the 16 building blocks

\section{Caracterização Hidrogeológica}

Dentre os parâmetros hidrogeológicos estudados, enfatiza-se a recarga dos aquíferos da Folha SA-23 - V - C - I -1-SO, tendo como base estudos sobre a geometria dos sistemas geológicos e dados do comportamento do fluxo subterrâneo do sistema hidrogeológico livre.

\section{Geometria dos Sistemas Hidrogeológicos}

$\mathrm{O}$ arranjo espacial dos pacotes sedimentares foi modificado pela atuação neotectônica, refletindo-se em mudanças no caimento das camadas que agora se encontram em posições diferentes daquelas que tinham quando da sua deposição. Essas mudanças influem sobre as características 
dos aqüíferos quanto a continuidade lateral, fluxo, recarga, vazão, etc.

Para avançar nas definições da geometria dos sistemas hidrogeológicos da área foi realizado levantamento geofísico utilizando o método geoelétrico de eletrorresistividade, mais especificamente sondagens elétricas verticais - SEV. Essas SEVs foram correlacionadas à perfis de poços situados próximos a estas.

Com base em oito sondagens elétricas verticais, posicionadas perpendicularmente aos principais alinhamentos de drenagem, foi possível avançar no entendimento da disposição das camadas litológicas em sub-superfície, definindo profundidade do topo das mesmas, bem como suas espessuras, assim como foi possível elaborar seções dessas camadas litológicas em sub-superfície (Figura 7 e 8). Nestas seções observa-se:

$\checkmark \quad$ Camadas aquíferas compostas por arenitos e calcarenitos, justapostos a camadas impermeáveis a semi-permeáveis representadas geralmente por argilitos, folhelhos e siltitos;

$\checkmark$ Descontinuidades (prováveis falhas) com rejeitos verticais impostas pela atuação neotectônica que alcançam dezenas de metros (desníveis de mais de 20m);
Variação lateral das espessuras de camadas, além de eventuais desaparecimentos de camadas, observadas em seções contíguas;

Indicação de desenvolvimento de um arranjo estrutural em blocos com formação de estruturas do tipo horst e graben.

A visão integrada dos dados de SEVs, associados às informações da geologia de superfície e aos dados de poços, permitiu definir três sistemas hidrogeológicos: Superior, Barreiras e Pirabas.

$\checkmark \quad$ O Sistema Hidrogeológico Superior pode ser encontrado a partir de 2 a $8 \mathrm{~m}$ de profundidade, com espessura média de $12 \mathrm{~m}$ e caracteriza-se como livre;

$\checkmark \quad$ O Sistema Hidrogeológico Barreiras encontra-se entre 20 a $30 \mathrm{~m}$ de profundidade, com espessura média de $25 \mathrm{~m}$. Caracterizado como livre a semiconfinado;

$\checkmark \quad$ O topo do Sistema Hidrogeológico Pirabas pode ser encontrado entre 90 e $115 \mathrm{~m}$ de profundidade. Este sistema é sobreposto por uma camada argilosa espessa, que caracteriza o sistema como confinado, quando se considera apenas os aspectos geométricos de sucessão de camadas. Com os dados disponíveis, esse sistema se prolonga até profundidades de $150 \mathrm{~m}$.

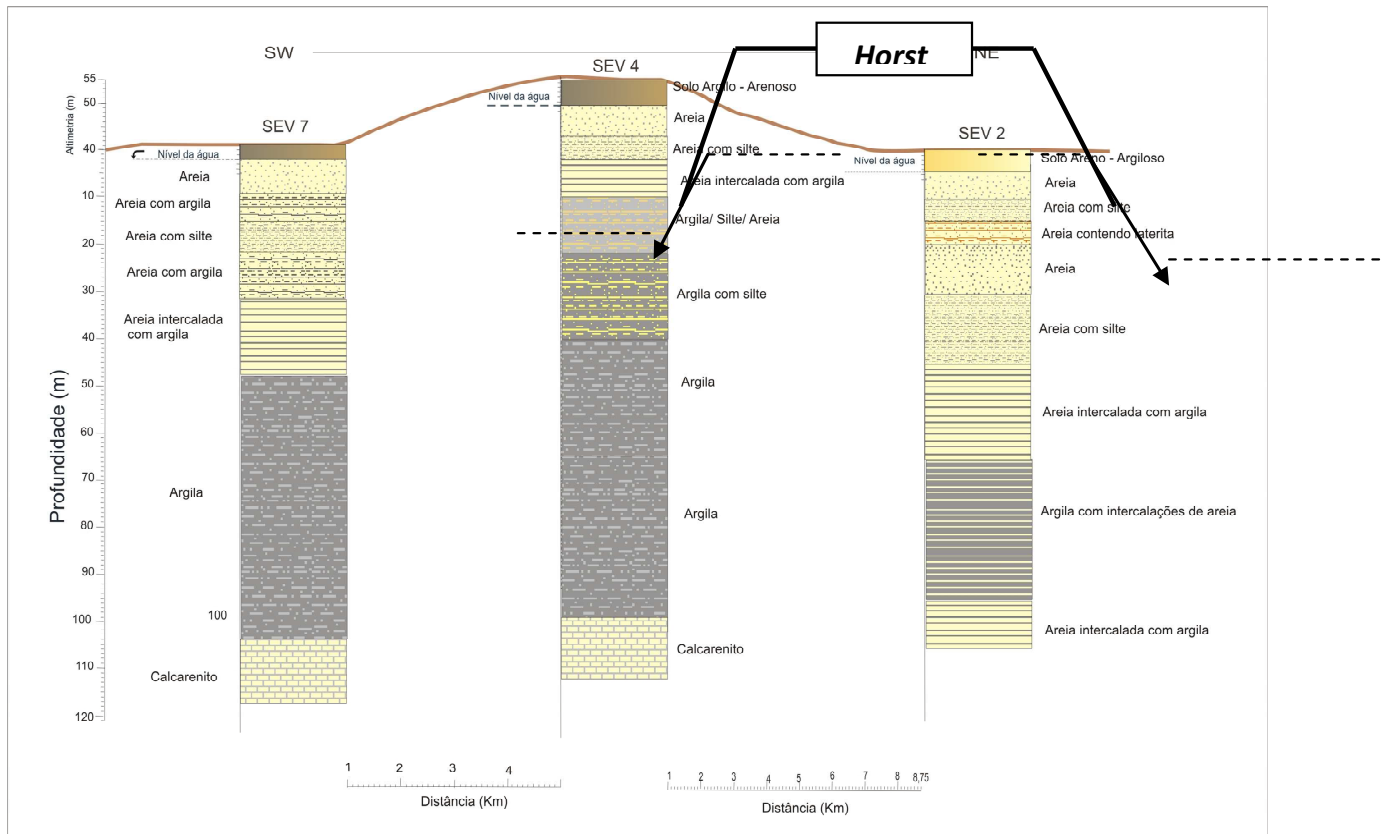

Figura 7 - Seção NW-SE - mostrando mergulho das prováveis falhas nos sentidos SW e NE, configurando um horst

Figure 7 - Section NW-SE - showing probable faults' depth in SW and NE directions, forming a horst 


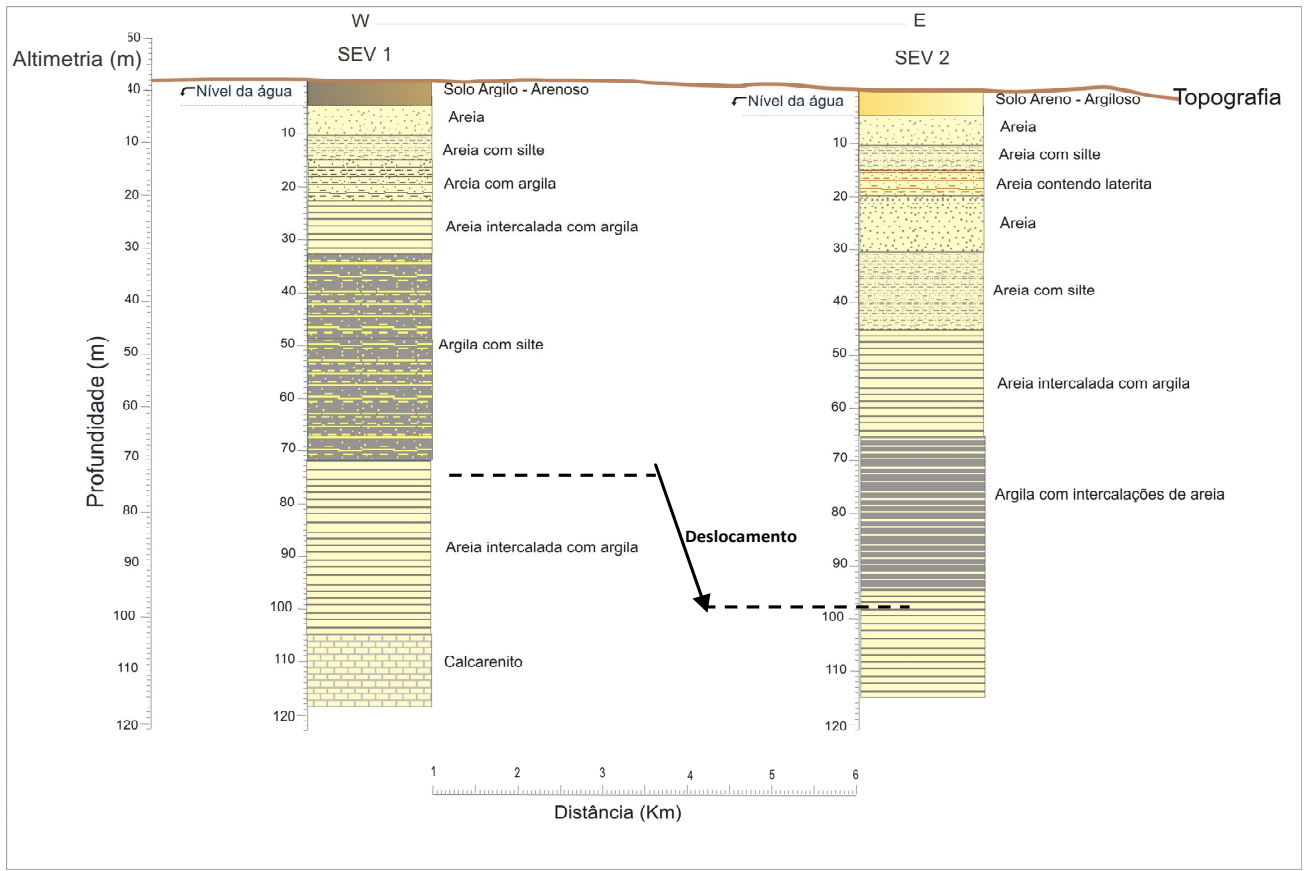

Figura 8 - Seção W-E mostrando o deslocamento das camadas (areia com silte) e indicação de falha com mergulho no sentido leste

Figure 8 - WE section showing the disrupt of layers (sand with silt) and fault indication with dip towards east

\section{MAPEAMENTO DO FLUXO SUBTERRÂ-}

\section{NEO}

O mapeamento do fluxo hídrico subterrâneo considerou os sistemas hidrogeológicos livres, ou seja, o Superior e provavelmente o Barreiras (livre e/ou semiconfinado). Não pode ser feito um estudo do fluxo para o sistema hidrogeológico Pirabas, pela insuficiência de dados, principalmente de poços profundos, além de serem poucos os poços (acima de $50 \mathrm{~m}$ de profundidade) que alcançam este sistema hidrogeológico.

O mapeamento do fluxo subterrâneo foi realizado em dois momentos distintos: no mês de menor precipitação (setembro) e no de maior precipitação (março). Os objetivos buscados foram: entender melhor o comportamento do fluxo hídrico e indicar possíveis áreas de recarga e descarga do Sistema Hidrogeológico Superior. A partir de medidas do nível estático de 38 poços (Tabela 3) foram construídos dois mapas de fluxo subterrâneo (Figuras 9 e 10). O comportamento da superfície potenciométrica mostrada nos dois mapas (Figura 9 e 10) são semelhantes, ou seja, o fluxo exibe uma inclinação do centro oeste pra noroeste e leste, acompanhando a inclinação do relevo. Devido a estas semelhanças os gradientes hidráulicos não tiveram inversões, assim como as áreas de recarga e descarga continuaram as mesmas. Mesmo havendo uma diminuição dos valores do nível da água nos poços, devido a baixa precipitação pluviométrica do período não chuvoso, o fluxo permaneceu no sentido das águas subterrâneas para as águas superficiais, ou seja, não houve inversão de fluxo.

Os gradientes hidráulicos, contudo, variam na área, indicando uma mudança de velocidade do fluxo. Na porção noroeste o valor do gradiente varia de 0,0024 a 0,001 , já na porção norte o valor é de 0,0035, indicando fluxo mais veloz. Na porção nordeste o valor é de 0,0034 , no leste é de 0,0008 , fluxo com velocidade menor. No oeste é de 0,0023 velocidade mediana. No centro é de 0,0022 , no sudeste é de 0,0018 , no sudoeste é de 0,001 . 
Tabela 3 - Características dos Poços Utilizados para o Mapa de Fluxo Subterrâneo

Table 3 - Characteristics of wells used for the map of groundwater flow

\begin{tabular}{|c|c|c|c|c|c|}
\hline Poço & $\mathrm{X}(\mathrm{W})$ & $\mathrm{Y}(\mathrm{N})$ & Cota & $\begin{array}{c}\text { Nível Estático } \\
\text { (Período mais chuvoso- } \\
\text { março) }\end{array}$ & $\begin{array}{c}\text { Nível Estático } \\
\text { (Período menos chuvoso - } \\
\text { setembro) }\end{array}$ \\
\hline $\mathrm{C} 01$ & 175113 & 9877242 & 41 & 7 & 7,5 \\
\hline $\mathrm{C} 02$ & 174019 & 9878216 & 39 & 6 & 6,4 \\
\hline $\mathrm{C} 03$ & 176620 & 9875832 & 43 & 6,5 & 7 \\
\hline $\mathrm{C} 04$ & 179736 & 9875506 & 46 & 10 & 10,7 \\
\hline $\mathrm{C} 05$ & 179485 & 9873558 & 35 & 11 & 11,7 \\
\hline $\mathrm{C} 06$ & 174126 & 9876122 & 47 & 5 & 5,8 \\
\hline $\mathrm{C} 07$ & 172054 & 9876260 & 43 & 6,1 & 6,9 \\
\hline $\mathrm{C} 08$ & 170479 & 9876592 & 33 & 5,6 & 5,9 \\
\hline $\mathrm{C} 09$ & 174980 & 9874016 & 50 & 8 & 8,3 \\
\hline $\mathrm{C} 10$ & 172725 & 9874142 & 40 & 3 & 3,9 \\
\hline $\mathrm{C} 11$ & 174474 & 9870968 & 37 & 2,5 & 2,6 \\
\hline $\mathrm{C} 12$ & 176558 & 9870532 & 42 & 5 & 7,6 \\
\hline $\mathrm{C} 13$ & 178774 & 9868762 & 38 & 5,5 & 7,4 \\
\hline $\mathrm{C} 14$ & 175834 & 9871158 & 35 & 4 & 4,8 \\
\hline $\mathrm{C} 15$ & 174309 & 9866238 & 37 & 3,7 & 4,1 \\
\hline $\mathrm{C} 16$ & 175996 & 9864496 & 42 & 5,3 & 7 \\
\hline $\mathrm{C} 17$ & 178227 & 9862080 & 34 & 1,8 & 2,1 \\
\hline $\mathrm{C} 18$ & 176558 & 9860060 & 37 & 2,5 & 3,1 \\
\hline C19 & 172235 & 9868374 & 45 & 2 & 2,8 \\
\hline $\mathrm{C} 20$ & 170588 & 9870044 & 51 & 6 & 6,7 \\
\hline $\mathrm{C} 21$ & 169137 & 9871258 & 37 & 2,8 & 3,3 \\
\hline $\mathrm{C} 22$ & 166529 & 9871080 & 46 & 4 & 4,4 \\
\hline $\mathrm{C} 23$ & 164303 & 9873546 & 41 & 7 & 7,8 \\
\hline $\mathrm{C} 24$ & 166533 & 9875530 & 34 & 3 & 3,2 \\
\hline $\mathrm{C} 25$ & 168315 & 9876362 & 33 & 2 & 3,8 \\
\hline $\mathrm{C} 26$ & 164774 & 9869984 & 46 & 0,9 & 2,8 \\
\hline $\mathrm{C} 27$ & 165302 & 9868314 & 46 & 0,8 & 2,1 \\
\hline $\mathrm{C} 28$ & 167536 & 9867714 & 51 & 0,8 & 2,9 \\
\hline $\mathrm{C} 29$ & 170375 & 9865106 & 46 & 1,4 & 2 \\
\hline $\mathrm{C} 30$ & 171011 & 9863162 & 43 & 4,8 & 5 \\
\hline $\mathrm{C} 31$ & 171976 & 9861788 & 45 & 8,4 & 8,8 \\
\hline $\mathrm{C} 32$ & 174319 & 9860056 & 51 & 10,9 & 10 \\
\hline $\mathrm{C} 33$ & 174165 & 9863422 & 41,5 & 3,4 & 3,5 \\
\hline $\mathrm{C} 34$ & 175971 & 9864274 & 47,5 & 8 & 8,7 \\
\hline $\mathrm{C} 35$ & 178980 & 9861344 & 38 & 3,9 & 5,2 \\
\hline $\mathrm{C} 36$ & 162539 & 9867568 & 38,5 & 2 & 2,7 \\
\hline $\mathrm{C} 37$ & 165265 & 9865210 & 45,5 & 1,8 & 2,5 \\
\hline $\mathrm{C} 38$ & 166497 & 9862334 & 47 & 6,7 & 7,2 \\
\hline
\end{tabular}




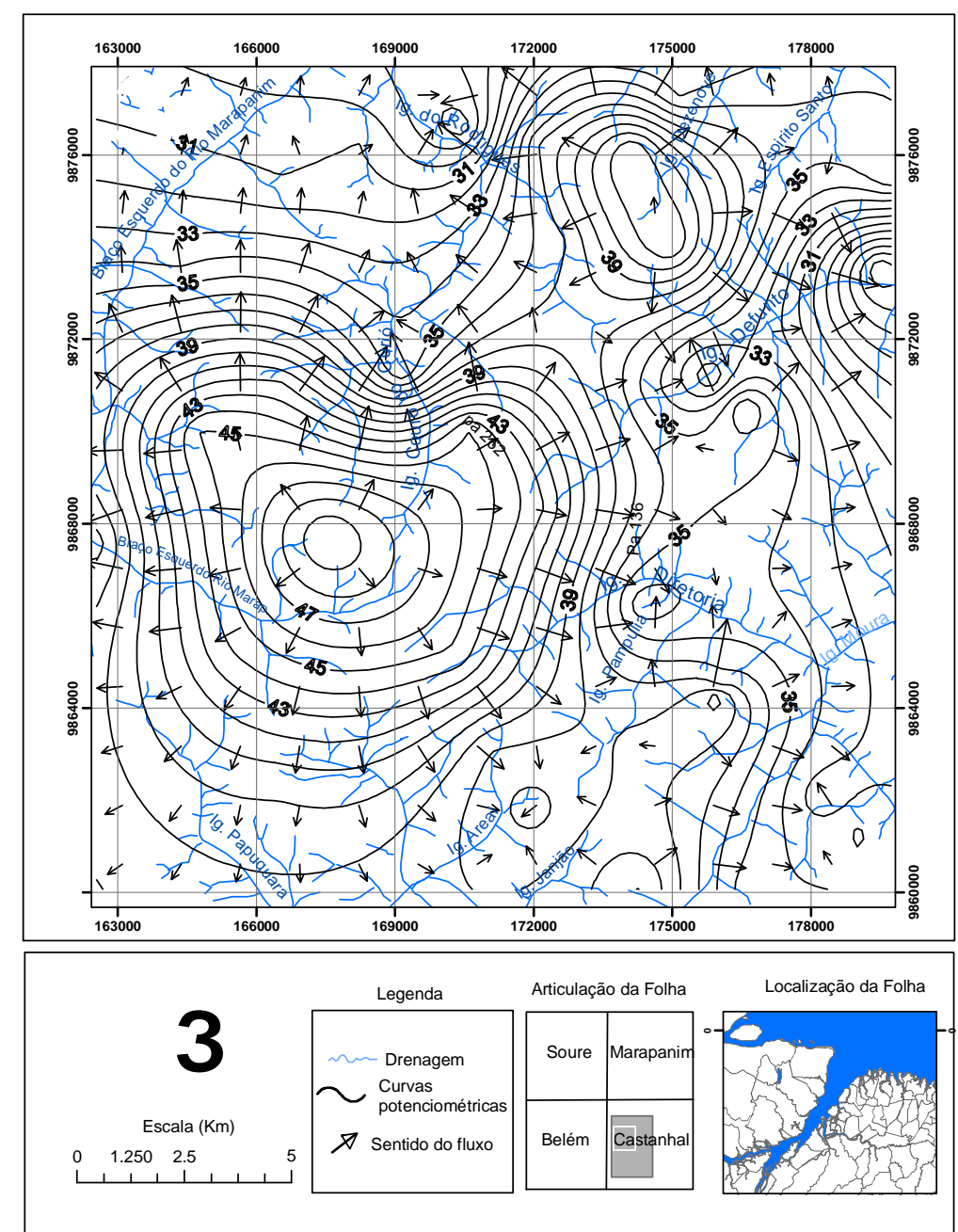

Figura 9 - Mapa de Equipotencial Hidráulico do período mais chuvoso da Folha SA-23 $-\mathrm{V}-\mathrm{C}-\mathrm{I}-1-\mathrm{SO}$

Figure 9 - Hydraulic equipotential map of the rainiest period of the Sheet SA-23 $\mathrm{V}$ - C - I -1-SO.

Fonte: Bandeira and Abreu (2009)

Source: Bandeira and Abreu (2009)
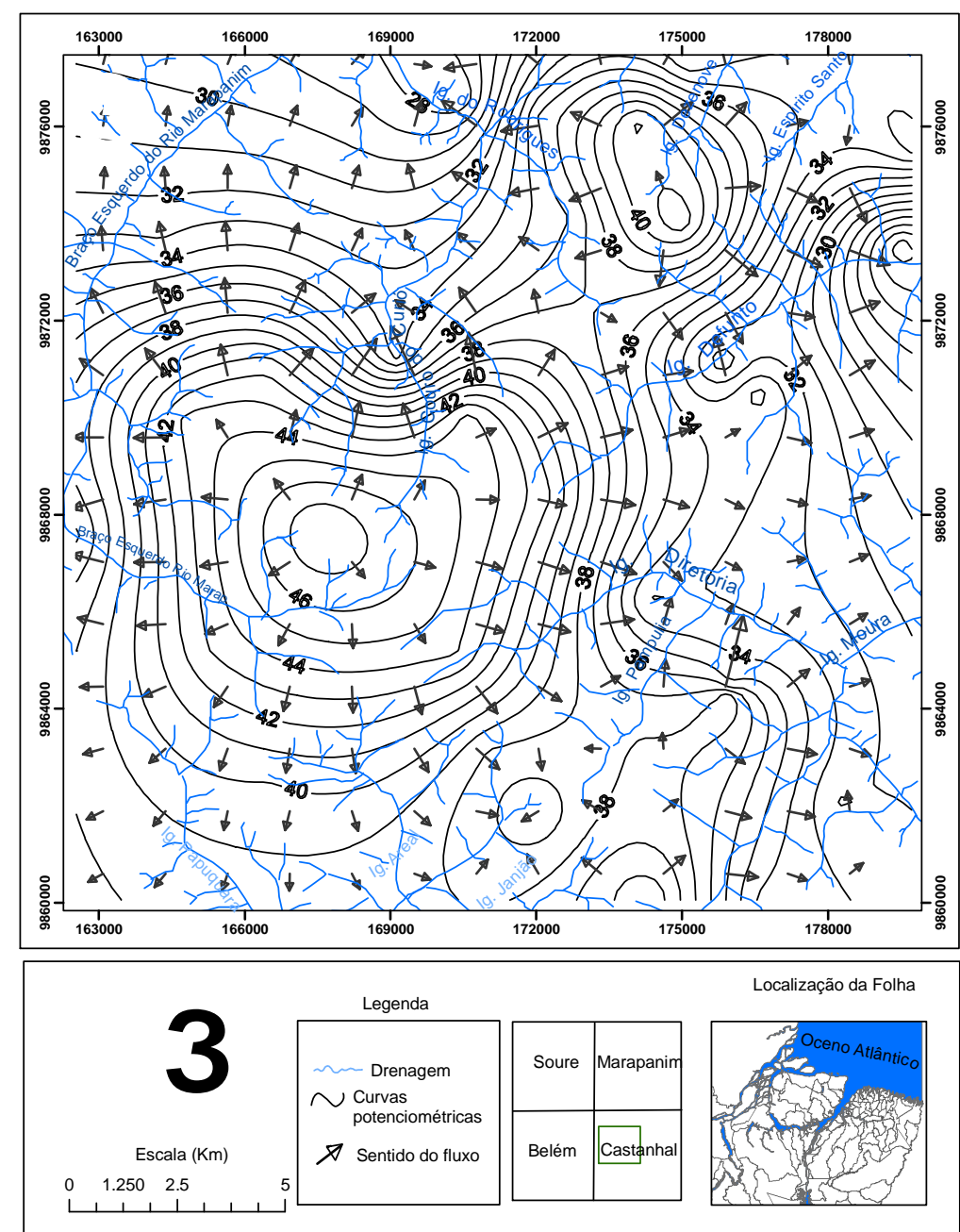

Figura 10 - Mapa de Equipotencial Hidráulico do período menos chuvoso da Folha SA-23 - V - C - I -1-SO

Figure 10 - Hydraulic equipotential map of the less rainy period of the Sheet SA-23 - V - C - I -1-SO

Fonte: Bandeira and Abreu (2009)

Source: Bandeira and Abreu (2009) 
Disso decorrem implicações ambientais, uma vez que as áreas com gradiente hidráulico maior, como na porção norte (próximo ao Igarapé Rodrigues), noroeste (montante do Igarapé couro de Curió) e nordeste (montante do Igarapé espírito Santo) terão processos de dispersão de contaminantes mais rápidos, no caso deles existirem na área.

Os mapas de fluxo subterrâneo do Sistema Hidrogeológico Superior quando analisados no contexto da base física construída para a área estudada (Figura 9 e 10), mostram de forma bastante clara a existência de, pelo menos, duas áreas de recarga do sistema hidrogeológico superior. A região de recarga é caracterizada pelo padrão divergente dos vetores de fluxo, e pode ser observado na porção centro-oeste, nas proximidades do Igarapé Couro do Curió e na porção nordeste do mapa (Figura 9 e 10), próximo ao Igarapé Defunto.

\section{Recarga dos Sistemas Hidrogeológicos}

A recarga dos sistemas hidrogeológicos comporta diferentes situações que podem ser assim descritas:

a) A recarga dos sistemas hidrogeológicos livres (Superior e Barreiras) se dá basicamente pela precipitação direta, a partir da água da chuva, na porção centro-oeste da área de estudo, ou seja, nas proximidades do Igarapé Couro do Curió e na porção nordeste próximo ao Igarapé Defunto (Figura 11).

Esta recarga é favorecida pela geologia da área caracterizada por sedimentos permeáveis na parte superior do pacote sedimentar, pelas condições atmosféricas e condicionantes impostos pela neotectônica;

b) Duas possibilidades podem ser consideradas para a recarga dos sistemas hidrogeológicos confinados (Pirabas) a semi-confinados (Barreiras);

$\checkmark \quad$ A primeira seria a infiltração a partir das áreas onde essas formações geológicas afloram, situadas distalmente a leste de Castanhal, ou seja, nos municípios de Salinas, São João de Pirabas, Capanema, etc., distantes aproximadamente $70 \mathrm{~km}$ da área de estudo. A partir dessas áreas a água migraria, recompondo os volumes de água subterrânea, nos locais de maior para menor carga hidráulica. Uma dificuldade nesse caso seriam os deslocamentos verticais provocados por falhas que interrompem a continuidade lateral das camadas aquíferas, dificultando essa migração.

A segunda possibilidade estaria relacionada a um condicionamento estrutural, no qual a recarga em parte ocorreria diretamente na área de Castanhal, onde a infiltração aconteceria, através dos condutos naturais que seriam as zonas de falhas e fraturas que interceptam as formações geológicas e permitem a conexão hidráulica entre os sistemas hidrogeológicos mais superiores e esses mais profundos (PINHEIRO, 2009).

Dentre essas merecem destaque as posições atrativas que na área são basicamente aquelas orientadas NW-SE, conforme os modelos cinemáticos estabelecidos, os locais de maior favorabilidade de recarga dos sistemas hidrogeológicos. Estas áreas de recarga apresentam compatibilidade às zonas de recarga definidas com base na análise do mapa de fluxo para o sistema hidrogeológico superior (Figura 9 e 10). 

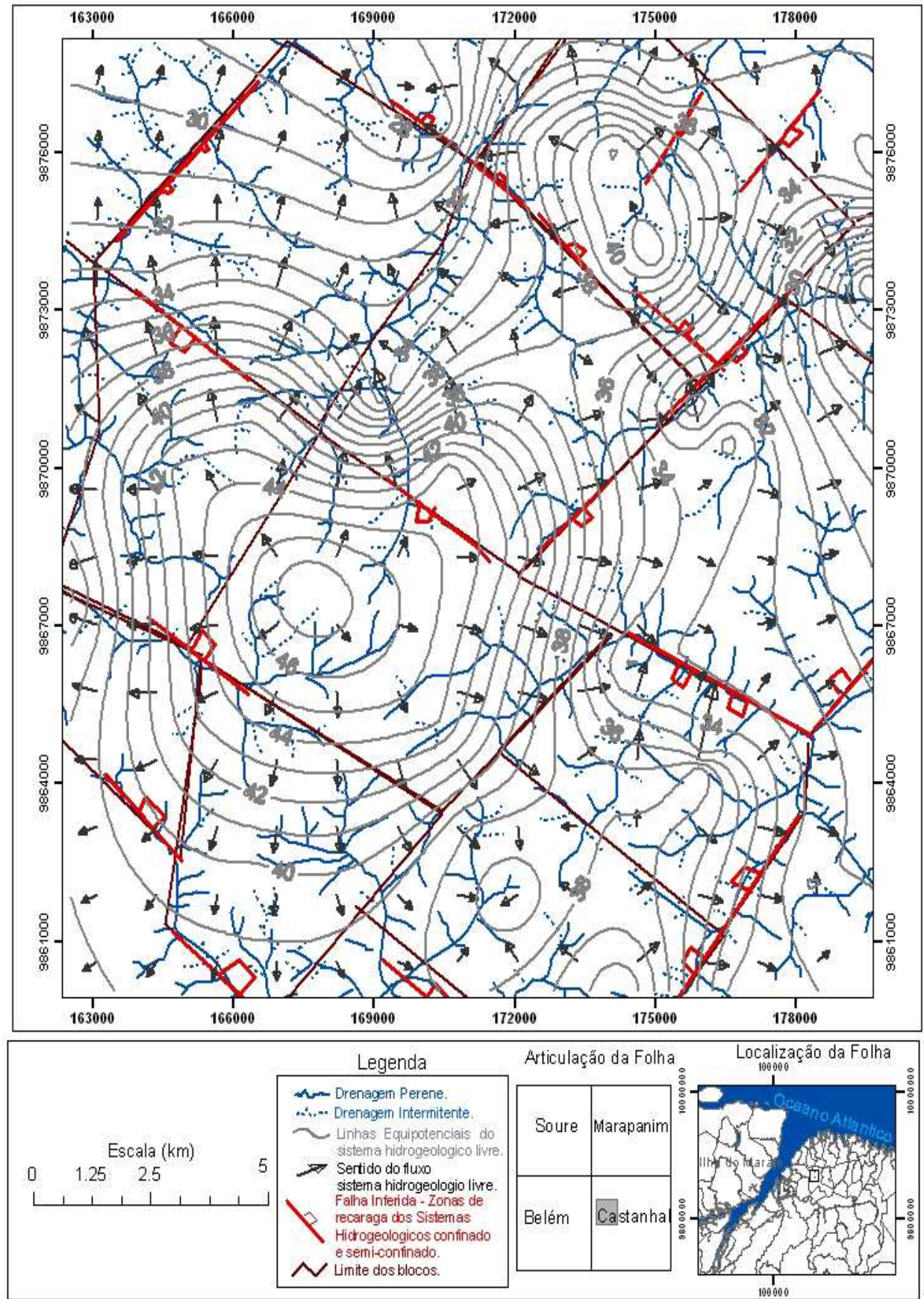

Figura 11 - Mapa das prováveis áreas de recarga da Folha SA-23 - V - C - I -1-SO

Figure 11 - Map of the Sheet SA-23 - V - C - I -1-SO probable recharge areas

\section{Interrelação Neotectônica e Hidrogeologia}

A inter-relação entre a geologia, análise

Desta forma a movimentação neotectônica morfoestrutural e hidrogeologia, permitiu estabele- ocorrida na área estudada gerou falhas normais na cer que a área estudada está dentro do contexto direção NW-SE, provocando desnivelamento de neotectônico regional caracterizado por transcor- blocos, responsáveis pela geração de landforms rências, com componente transpressivo NW-SE e tectônicos alinhados segundo duas direções princitranstensivo NE-SW, onde se desenvolveram pais: NW-SE e NE-SW. Também foram geradas falhas normais na direção NW-SE com mergu- falhas na direção NE-SW e falhas transcorrentes lhos no sentido NE (COSTA et al., 1996). destrais na direção E-W, comprovadas pelo apare- 
cimento de formas anômalas em $\mathrm{Z}$ na porção leste dos rios Inhangapi e do rio Marapanim.

Estas falhas impuseram um condicionamento estruturado ao relevo das planícies fluviais, colinas pediplanizadas e colinas de topos aplainados, alinhando-o segundo as direções: $\mathrm{N} 20^{\circ}-40^{\circ} \mathrm{W}$, $\mathrm{N} 60^{\circ}-70^{\circ} \mathrm{W}, \mathrm{N} 30^{\circ}-50^{\circ} \mathrm{E}$ e $\mathrm{N} 60^{\circ}-70^{\circ} \mathrm{E}$. Assim como condicionou a drenagem, impondo padrões como treliça, retangular e paralelo, e anomalias de drenagens como retilinearidade, aparecimento abrupto e localizado de meandros, estreitamento anômalo de vales ou canais e curvas anômalas.

As falhas normais passaram a interagir com as transcorrentes formando um arranjo alternado de blocos altos e baixos com mergulhos no sentido NE e outros no sentido SW.

Este arranjo em blocos também impôs modificações na configuração geométrica das camadas sedimentares em subsuperfície tais como:

$\checkmark$ Mudanças de atitudes das mesmas, devido aos deslocamentos e basculamentos;

$\checkmark$ Deslocamentos de 8 a $20 \mathrm{~m}$ de rejeito vertical colocam lateralmente camadas não tão espessas e de composições diferentes, interrompendo o fluxo subterrâneo e criando obstáculos para o fluxo a partir das áreas de recarga onde as formações afloram. Ou seja, a configuração em blocos gera comportamentos diferenciados para o fluxo hidráulico, condicionando a velocidade do mesmo ao basculamento das camadas, gerando assim superfícies potenciométricas distintas para cada bloco. Portanto, os mapas das superfícies potenciométricas devem ser avaliados com cuidado, levando em consideração cada bloco;

$\checkmark$ O caráter interdigitado das camadas, dificultando a determinação das espessuras saturadas. Sendo assim a estruturação em blocos introduz a necessidade de se estabelecer metodologias de cálculo de reservas subterrâneas, para cada bloco individualmente.

A distribuição das tensões na área, com base nas interpretações dos elementos estruturais identificados, produziram falhas normais de direção NW-SE, caracterizadas como zonas trativas ou superfícies potenciais de menor pressão que:

$\checkmark$ Constituem locais de maior favorabilidade para recarga dos sistemas hidrogeológicos. Logo os sistemas semiconfinados Barreiras e confinado Pirabas mesmo não aflorando na área de estudo, estão sendo alimentados a partir de águas pluviais e pelas drenagens controladas por essas falhas;

$\checkmark$ Possibilitam a conexão hidráulica entre os sistemas hidrogeológicos. Esta ligação permite que as águas do sistema hidrogeológico livre e menos profundo cheguem até os sistemas semiconfinado Barreiras e confinado Pirabas, provocando mistura das águas, fato confirmado por dados de Paranhos (2008) para a cidade de Belém, distante $56 \mathrm{~km}$ da área de estudo. Logo estas zonas constituem áreas potencialmente condutoras tanto de água de boa qualidade, assim como substâncias nocivas a saúde humana, caracterizando-se como zonas vulneráveis aos sistemas hidrogeológicos mais profundos como o Pirabas, considerado o melhor sistema para captação de água de boa qualidade em toda a região nordeste do estado do Pará. Quando atravessam as camadas calcárias trazem a potencialização dos mecanismos de dissolução, justamente por serem áreas de fluxo mais evidente. Daí a grande probabilidade do desenvolvimento de edifícios cársticos.

\section{CONCLUSÕES}

As pesquisas, análises e interpretações realizadas neste trabalho permitiram concluir que a metodologia para a interpretação morfoestrutural, baseada na análise dos padrões de drenagem e relevo e o estudo hidrogeológico baseado em dados de sondagens elétricas verticais, e mapeamento do fluxo subterrâneo, possibilitaram mostrar que existe um condicionamento estrutural na área, caracterizado geometricamente por falhas distensivas de direção NW-SE e estruturas E-W, NW-SE e N-S.

A interação entre falhas provocou na área um arranjo geométrico caracterizado por blocos estruturais romboédricos que também foram desnivelados por movimentações verticais gerando altos e baixos estruturais, causando modificações nas camadas sedimentares em subsuperfície, favorecendo assim à penetração vertical da água. Isto é, os sistemas semiconfinado (Barreiras) e confinado (Pirabas) estão sendo recarregados in situ por meio destas zonas. Já os sistemas hidrogeológicos livres estão sendo recarregados na área de Castanhal, por água da chuva, no período de maior precipitação (janeiro a agosto), principalmente nas porções centro-oeste da área, ou seja, nas proximidades do iga- 
rapé Couro do Curió e na porção nordeste próximo ao igarapé Defunto.

Além de possibilitar a recarga dos sistemas hidrogeológicos estas falhas consideradas superfícies de menor pressão facilitam a conexão hidráulica entre as camadas saturadas, ocasionando a mistura das águas dos sistemas hidrogeológicos presentes na área. Disso decorre uma grande preocupação,

\section{REFERÊNCIAS}

ARGENTO, M. S. F. Mapeamento geomorfológico. In: ARGENTO, M. S. Geomorfologia uma atualização de bases e conceitos. Rio de Janeiro: Bertrand Brasil. 2001. p. 365-386.

BANDEIRA, I. C. N.; ABREU, F. de A. M. de. Principais áreas de recarga do sistema hidrogeológico livre, da Folha Sa. 23 - V - C - I -1-SO e suas implicações ambientais. In: Congresso Internacional de Meio Ambiente Subterrâneo, 2009, São Paulo. Resumos... São Paulo: ABAS, 2009.

BERROCAL, J. et al. Sismicidade do Brasil. São Paulo: Esperança; IAG/USP - Comissão Nacional de Energia Nuclear, 1984. 320p.

COSTA, J.B.S.; BEMERGUY, R.L.; HASUI, Y.; BORGES, M.S.; FERREIRA JÚNIOR, C.R.P.; BEZERRA, P.E.L.; COSTA, M.L.; FERNANDES, J.M.G. Neotectônica da região Amazônica: aspectos tectônicos, geomorfológicos e deposicionais. Geonomos, v.4, n. 2, p. 23-44, 1996.

COSTA, F. R. da. Influência da neotectônica sobre os arranjos geométricos dos aquiíferos na Região Metropolitana de Belém. 2004. 157 f. Dissertação (Mestrado em Geologia e Geoquímica)- Instituto de Geociências, Universidade Federal do Pará, Belém, 2004.

HOWARD, A. D. Drainage analysis in geologic interpretation: a summation. Bulletin American Association of Petroleum Geologist, v. 51, n.11, p. 2246-2259, 1967.

LIMA, E. P.; QUARESMA, J. B.; NÓBREGA, E. A. T. Modelo de um aterro sanitário para disposição final de resíduos sólidos na cidade de Castanhal e o estudo de impacto ambiental. Belém: Universidade Federal do Pará/ Núcleo de Meio Ambiente, 1994. 72 p. (Estudo do NUMA 1).
OLIVEIRA, J. R. (Coord.). PHRMB - Projeto Estudos Hidrogeológicos da Região Metropolitana de Belém e adjacências. Belém: CRPM, 2003. 1 CD-ROM. (Relatório Final).

PARANHOS, P. F. Caracterização hidroquímica dos aquíferos Pirabas na região de Icoaraci-Pa. 2008. 120 f. Dissertação (Mestrado em Geologia e Geoquímica)- Instituto de Geociências, Universidade Federal do Pará, Belém, 2008.

PINHEIRO, A.V.R. Uso de ferramentas multidisciplinares na avaliação de vulnerabilidade e risco a subsidência no meio cárstico na cidade de Castanhal, nordeste do Pará. 2009. 244 f. Tese (Doutorado em Geologia e Geoquímica) Instituto de Geociências, Universidade Federal do Pará, Belém, 2009.

PARÁ. Secretaria Executiva de Transportes. SIGIEP - Sistema de Informações Geográficas do Estado do Pará. Belém, 2000. 1 CD ROM.

SOARES, P.C; FIORI, A. P. Lógica e sistemática na análise e interpretação de fotografias aéreas em geologia. Notícia Geomorfológica, Campinas, v.16 n. 32, p.71-104, 1976.

SOUZA JUNIOR, C. M.; QUADROS, M. L. do E. S.; BEZERRA, O. V. Projeto: relatório final estágio de campo III, município de Castanhal. Belém: Universidade Federal do Pará, 1992.

STEWART, L. S.; HANCOCK, P. L. Neotectonics. In:. HANCOCK, P. L (Ed.). Continental Deformation. New York: Pergamon Press, 1994. p. 370-409.

THORNTHWAITE, C. W.; MATHER, J. R. The water balance. Climatology, v. 8 n. 1.b, 1955 